\title{
3 Money (and Materiality)
}

Nothing gold can stay

Robert Frost

It 'answereth all things', as averred in the Bible - and it is, without doubt, the prime, quintessential, mover of American activity (sex, remember was only a - debilitating - pastime), answering to all, with no questions asked. It would be quite fitting accordingly, for noblesse must oblige, if corporate planners, someday, decided to erect a giant dollar sign that canopied the country, dragging in Guam, and Hawaii as well, reassuring all of us, including the few who might yet be in doubt, as to the terms of our real tutelage. Kings, classes, castes, and cartels, in history, have all admittedly been avidly, even rapaciously, covetous, but greed has never encompassed an entire civilization, lock, stock and barrel, subverting all processes, from sea to shining sea, without blush or murmur, as in this, the original Graceland of Mammon.

Money is its warp and woof, its manifest destiny, its alpha and omega, its gospel on earth, its mission to the world, its claim to everlasting godhead. Christ is said to have been betrayed in times of yore for thirty, undepreciating, pieces of silver; for far less (indeed for nothing at all), on the street, you can be robbed, beaten, killed, maimed and mutilated. But the street is only a minor, micro replay, of a much larger, more deadly, game played internationally by the varied enterprises of America, Inc.; to defend the Righteous Regime (another enduring American characteristic: our insufferable righteousness, even as we do knowing wrong! It is indeed quite a marvel to behold) of the dollar, and its self-serving game rules, enshrined in pax Americana, continents have been pillaged, nations plundered, and entire societies put to the sword, torched, ravaged, bombed, burnt, napalmed, gassed, and nuked.

Money is no modest preoccupation, no Midas-like 'rationally irrational passion for riches', no idle pursuit of wealth unbounded, but a rabid, narcotic, stupefying obsession that defies a true social description.

Of course, capitalism in its deadly, predatory form, as we know it today, arose in a much more circumscribed social matrix in the feudal bosom of the Old world, racing riotously across to the New only in the Sixteenth century or so. And the barbarism of vintage European capital is only too well inscribed in the annals of social history, in Literature, in Art, and in the decimated physical and social landscapes of the non-European world which were unfortunate enough to elicit European interest. But Europe, to this day (with the exception of war-ravaged and hence rebuilt Germany) still remains a fundamentally stalemated, conservative capitalism, in some respects, because there the new order of market society had to struggle for life against the older order of birth, privilege, and rank.

The regime of Mammon was, eventually, to slay the lumbering old feudal dragon, but only at cost of a social compromise, a truce between the old and the new, that still explains (and 'tis a curious mixture) both the economic dynamism and the social 
stasis of European society. But, here in America, there was no real opposition worth the name, the luckless heroism of the original inhabitants of the land (and the exaggerated exploits of Davy Crockett) notwithstanding: the hapless Native Americans were ruthlessly set upon, mercilessly decimated, and savagely driven into concentration camps, like so many stray cattle: their civilization undone, their lands stolen, their living culture scattered across the continents in so many pockets of smoldering, rankling, feculent decay.

Here, the barbarism of Mammon faced no social obstacle, no historical check, no cultural resistance, no ideological challenge, no natural barrier. And, like a pox festering in a sewer, it bred, multiplied, and eventually overran the continent, its demonic urges corrupting all that it touched, Midas-like, freezing the arteries of religion, society and politics.

The 'Business of America is Business', said Calvin Coolidge; but, it went without saying. From the original pirate-plunderers and privateers of His Majesty's Government, to the carpetbaggers and robber-barons of the nineteenth century, to the corporate Samurai of the twentieth-twenty-first, centuries, this industrial and mercantile empire (so much more of a free trade, single currency, zone, still, than a nation) was crafted by abundant wealth wedded to abominable power. Today, in popular ideology, the links between the two are mystified and hidden in many ways, though their loving symbiosis in reality is almost beyond question.

And what must happen to a society where money and markets are the ruling deities? Look around you, the contagion is everywhere; look inside you, and the emptiness that nests, in that nameless hollow that is you, is grieved of the same cankerous virus. 'Ill fares the land, to hastening ills a prey, where wealth accumulates, and men decay', sang Oliver Goldsmith, an English poet, disturbed by the death-dealing commercialization of eighteenth century English society. And what are these ills that the Bushmen of the Kalahari know not? If I were more biblically inclined, I would say, it's the Four Horsemen of the Apocalypse, but I am not; and besides, many more horsemen (and women) would be needed to describe the decay, physical and moral, the rot, both dry and wet.

Let's ponder this further. I am not saying that people in other times and other societies have not been venal, corrupt, greedy, and decadent. I come from India, so I can swear to the safe sanctuary that even that ancient society offers to such, not uncommon, traits. Debasement of values is everywhere, decay in civic conduct, universal. I have friends, and relatives, in India whose attachment to materiality, whose surrender to greed, whose sacrifices (usually of others!) on behalf of wealth, are qualitatively as impressive as the record of any Mellon, Carnegie, or Rockefeller; why then, you might ask, do I censor America alone for what is, admittedly, a world-wide obsession? What then, is the difference, between our 'ideal types' of India and the U.S.?

Let me return to our friends, Darla and Kamala, by way of explanation and illustration. Let me assume that Darla and Kamala are both in pursuit of the same material ends, ready to do all, to give all, to sacrifice all, to the headless Moloch of Mammon. 
And this assumption, in general, is not at all far-fetched; the stock-broker, the realty shark, and the money-lender are as cunning, devious, single-minded, and selfish, in India, as in America. In fact, to press the point further, the commercial wheeze and the business hustle - for not being subtle - is cruder, crasser, and perhaps even more annoying, in India than here (as the average tourist, negotiating impromptu hawkers in Indian city streets is aware). So, whence the difference? Why is there still hope for humanity in India, despite its steady erosion under America inspired 'Globalization', as I perceive it?

The answer rests in value structures, in civilizational differences, between the two worlds (India is no more a country than the US is; they are both worlds, civilizations, entire universes of distinguishable values, philosophies, and convictions). Societies differ (thank goodness!) not just materially, but ideologically, and culturally as well. The base, selfish, calculating, conduct of the loan shark is as real there as here; the difference is, that in India, as in older societies generally, such conduct does not carry positive social sanctions in ideology, either public or personal. And that is a crucial difference. Kamala may wield the knife astutely in conducts commercial, but (and I know Kamala) she will retain the guilt of it (if only a twinge and a pang) and will, sooner or later, try to atone for it. This she cannot help; it is part of her, part of her culture. This may not prevent her from being venal again the next day: but, fundamentally, she is not at ease with her actions; she is going against the grain of a social ethic, a general value structure, that will not help rationalize her actions, or justify her conduct.

I have an acquaintance in India who likes to lord it over his miserable lackeys, in the manner of the rich and the powerful the world over; one night, under the influence, he went to fiendish extents to humiliate one particular manservant - the chosen victim of his evening's power play - abusing and insulting him to a level almost unthinkable. The next morning, sobriety and trace residues of a lapsed conscience restored, the poor servant - who had borne all without murmur (a civilizational characteristic all by itself) - was showered with lavish gifts, including a small house and a garden; and, later that evening, his erstwhile oppressor was observed devoutly praying to his gods, begging forgiveness, seeking absolution, in all shamefaced repine.

Of course, the cycle would probably be repeated again, as it may have occurred other times before; but it was, ultimately, a civilizational value, much larger than the opulence of my friend and the largesse of his purely personal generosity, that demanded such restitution and contrition. Traditional ideology, unlike the totally amoral world-view of 'modernism', wherein all sins may be readily absolved, does not permit uncharitable social actions to be simply shrugged off.

Not so with Darla; nice guys finish up last, she's been taught since childhood, and all's fair in love, war, and commerce. She neither shows, nor expects to receive quarter. She virtually embodies, sadly true to stereotype, the keenest capitalist spirit of calculation and (if only a rather short sighted) self-interest. I missed some classes 
once (out of sheer disgust), at Columbia University, and returned, weeks later, to hear talk of an impending exam; I asked a fellow-student to tell me when it was supposed to be scheduled: 'you shouldn't have stayed away from all those classes', was the only reply I got. Yes, by god, I was in America.

In all societies, we have this conflict between values and actions, the de facto, and the de jure. But, in America alone (even Japan, the marvel of the capitalist world today, has not been able to emulate this energizing social trait, and therefore still 'lags behind', culturally) is there no hiatus between Theory and Practice. In curious ways, therefore, only in America is there complete honesty about being crooked: 'I am not going to mislead you', said an attorney friend of mine, 'I'll take you for every penny you've got' (he was, of course, to be as good as his word). If you're vulnerable, you expect to be rooked; the flip side is, if you're smart, you take what you can get when 'opportunity knocks' at your door. And so we are done in by others just as much as we are ready to do others in; and thus prey and predator begin to think alike (despite the immutable ontological difference between them) and share the same regressive premises.

It's a rather facile dog-eat-dog philosophy (and all the dogs I know, in my poaching grounds, seem to share it quite equably); the trouble is that we're discussing human society, in socio-biological, 'law-of-the-jungle' parlance. But look around: the jungle metaphor doesn’t seem quite so far-fetched (having lived in New York, I know real jungles may offer a higher margin of personal safety, composure, and dignity). Small wonder so much of American ideology - in which popular economic ideology plays a royal role - faithful to its habitat, is cast so starkly in Darwinian, survivalof-the-fittest, terms. Take the typical Western, America's only serious movie genre, where the anti-hero (simpler, and older, societies still not decanted of basic decencies, celebrate admittedly wimpish, syrupy, heroes; America, hard-headedly, hoorays the crypto-villains) delivers all the one-liners that make up the American psyche.

'You shot an unarmed man', yells the side-kick, in a recent nostalgia Western; 'he shoulda armed himself', drawls back Clint Eastwood, the Bad-Guy hero, to the chuckles of the hall. That's American ideology, in a nutshell. Nice guys finish up last, the slow (or the stupid) wind up dead (an aside: I know a fellow academic, also from Asia, but settled here, with a well-deserved reputation for being extremely harsh and acerbic in his public debates; when I asked him why he chose such an unflattering public persona, since this behavior clearly belied his personality and breeding, he grinned a very boyish grin and said, 'This is America; they're always rooting for the bad guys'). There's machismo, violence, and amorality, all wrapped up in the red, white, and blue of Mr. Eastwood's portrayal of the classic American hero.

Amorality is a very important notion: in fact, it just about defines the Critique rendered in this book. Kamala thinks of her own loan-sharking practices as immoral, and suffers a little within her conscience; indeed, contrition is the obligatory homage vice pays to virtue. Of course, all social beings are capable of willful immorality whether in Italy, India, or Ireland; but to be amoral, i.e. to rise 'above'(!) the vulgar distinction 
between morality and immorality, right and wrong, is the privilege of a few, PostModernist, societies, in whose comity America is the standard-setter and standardbearer.

It is not that there necessarily is proportionately more wrong-doing in America than elsewhere ( although it is probably quite true: more murders, as we all know, in New York in a - good - month than England in a - bad - year, as English tabloids never fail to piously remind their readers. The peace of Tokyo, with a population in excess of 12 million is marred, perhaps, with Three fire-arm killings a year - in New York, with a population of some 10 million, it used to be in excess of Five hundred, though abating lately to about 414 in 2012; in California, the averages were above 1800 - and this has little to do with Japan being more 'homogeneous', as apologetics routinely avers in public commentary; India is even more heterogeneous than the US without correspondingly inspiring an escalation in the random, casual murder of civilians); it is, perhaps, that there is far less sensitivity to a distinction between right and wrong in America.

After all with morality a dead, or dying standard of reference, it is the law that is the only, if ineffectual, deterrent to misconduct. Not the law as a set of juridical codes, but the law (as Westerns have portrayed it for decades) as a set of armed men, with sixguns blazing, as recently exemplified in the recent FBI inspired holocaust at Waaco, Texas; nowhere in the world that I know of, except during civil wars, are cops as trigger-happy as in America, where you can be shot and killed legally (and with complete impunity) for jumping a subway turnstile, or stealing a can of soda from the corner grocery store (of course this outcome is virtually guaranteed if you're black or ethnic poor, benighted, George Jackson, young, black, and angry, was put away for life, and murdered in prison eventually, for holding up a gas station to the tune of a miserable twenty-five dollars, whereas Ivan Boesky, smug, white, and savvy, bilking hundreds of the unsuspecting for millions, got but a rap on the knuckles - but it also applies more generally).

For there is no organic 'society' to speak of here, barring some isolated, small communities, outside the mainstream of big-city America; think of how much more answerable you'd be to community sanctions if you shot and killed unarmed civilians, under the auspices of being a policeman, for petty crimes in any nation where the social bond has still not been entirely dissolved by capitalism: e.g., England, or Italy, or India (the Ford Motor Company, in context of the Pinto trial, and in all blandness, revealed the value placed on an average American life by the Corporate rulers; the eleven dollars, per car, requisite to set right the fuel tank vulnerability of the Pinto was, apparently, thought to be too high ). Again, I'm not saying such things do not happen elsewhere; but, elsewhere, they are (rightly) perceived as outrages, whereas in the US they are just more pedestrian fodder for the evening news, to be reported, and received, without comment, ceremony, or ado.

There are almost as many banks in New Delhi as in New York, for modern India is nothing if not securely bourgeois, but a private armed guard is, or rather used to 
be, a rarity in that Indian city (although the more recent 'terrorist' threat has made for far more visible displays of armor across India) - even the police, true to their British ancestry, carrying batons at the most. And then Citibank opened a branch in the late sixties; and lo and behold, true to form, there was an immense guard with an outsize rifle on duty! - the US managerial planners had simply carried their instincts over (the ultimate in the rampant symbolism of violent authoritarianism and intimidation, for me personally, was when I first encountered armed campus police in American universities: the foundational cement of American society, I thought then, was made up of elements not at all dissimilar to Hitler's Germany). A society where the brute force of the law, rather than a shared Ethic, is the only restraint against unsocial actions is already in the pit of complete dissolution of its social form (a full $94 \%$ of all lawsuits on this planet are filed in America). It is held together by that which is least abiding: force. Even Napoleon, that megalomaniacal, sword wielding, unilateral law-giver of Europe, understood the point when he said that you can do anything with bayonets except sit on them.

Wealth and amorality; wealth and the breakdown of social bonds: not a novel thesis at all. The Bible said it all, echoing many civilizations, aeons ago, in that neat little adage about the needle, the camel, and the rich man. And here we are, true to script, uncementing our social life, our real social bonds with each other, our nearest and dearest relationships, with the pure, unalloyed, manifest of greed. We don't need sociologists, social pathologists, or psychologists, to ponder the resulting erosion of social cohesion. All we have to do is to look around, observe, and digest.

The apathy, the coldness, the distance, the alienation of 'industrial life' is written about by professional hacks endlessly - but its root causes are all but ignored. The truth is too horrible for us to admit; capitalism corrupts, and absolute capitalism corrupts absolutely. Worse, when the dominant capital at issue is Finance capital (which,departing from its covert profile, has now fully captured the entire system, quite overtly), more reactionary and predacious, by far, than any other form. A French sociologist, Emile Durkheim understood matters well, though he preferred to use more euphemistic language about 'modernism' instead; he called the breakdown of the social 'anomie', or normlessness, a feeling of estrangement, dislocation, separation. Even Hollywood, in its mature adolescence (as opposed to its senile infantilism today), exploited the theme giving us James Dean as the embodiment of that 'rebel without a cause' hooey (although, cleverly, it tried to infer that it was mere puberty and youth that produced such angst, casting it as a condition that will be, naturally, self-effacing, as we 'grow up'); and all of rock music, at its progressive best, sings of it still.

The truth of this may be visualized in thinking of those few, scattered, isolated groups in America, relics of a past, though part-surviving, idealism, that have tried, consciously, to incorporate a non-capitalist ethic in their communal behavior: they, outside of the fragile, transient, have-not community of the ghetto, represent, perhaps, the last vestiges of the social in America (the Amish, in Pennsylvania, come 
to mind; the much larger community of Mormons in Utah are somewhat similar, though far more assimilated to mainstream practices). Living in Utah, I can attest to the difference the Mormons still make, even though their anti-capitalist strain expired generations ago, to at least the civic environment of Salt Lake City; just compare Utah to the likes of neighboring Wyoming and Nevada and you appreciate the difference instantly. Civic sense, an active sense of culture, and the ordinary courtesies of civilized society, still exist here, and are not merely the appropriations of a thin, remote, and sheltered elite; good neighborliness, community feeling, co-respective behavior can all be seen and felt - all in welcome contrast to the chilling savagery of public conduct, as say on a typical New York, Chicago, or L.A. street.

Barring marginalized exceptions like that, however, most of us have no community feeling, or sense of society, larger than our very immediate families, friends, parishioners, and co-workers, which reduces to a truncated microcosm of the larger whole. Darla may be unusual, but at last count she had one 'real' friend and one relative - her mother - whom she had regular relations with (which makes for a 'society' of three, give or take the recurring boyfriends): all others, in the megapolis she lives in, reduced to just so much irrelevant, background noise.

Small wonder the system generates 'individualism' as a compensating, justificatory, ideology for the already severely truncated domain of the social; we have been reduced, not raised, as is popularly believed, to the level of the anxiety-ridden, distraught, lonely, quasi-neurotic individuals, seeking to huddle together for comfort, when we are sane enough to understand our plight, and losing ourselves almost completely in trivial pursuits, on the grey borderline of sanity, when we don't (or when we are afraid of the truth).

Clever, and unscrupulous purveyors of make-shift tv religions have preyed on this morass of loneliness for years, only recently tripping up and revealing their own hideous rapacity, whether in the failed or faltering ministries of the likes of Oral Roberts, the Swaggarts, the Bakkers, etc. Religion? No, they were producing a pseudocommunity for the old, the desperate, the ailing, the hopeless, if at rather a high cost, extorted from the vulnerable, the weak, the helpless. Religion in America? For the rich, it is a suitably elegant fraud, for the ruling class a reassurance of order and their anointed place in it, for the poor a sop, a rope, a straw, to clutch on to in the fervid hope that the next world treats them better than this one.

It's funny in a way, though; there are probably more registered religions in America than the rest of the world taken together (as the joke runs, America has four hundred religions and only three cheeses; in France, it's the other way round). But all that is a farce and a sham; there is only one true religion in America, and one dismal shrine at which we all worship lustily, regardless of race, denomination, gender or creed: and that is the all powerful, merciless, blinding, faithless, lord of lucre (my smug New York friends laughed derisively when informed of my move to Utah; how could you possibly live amongst Mormons?, they asked, in disbelief. And I kept quiet, for we Brahmins are raised as nothing if not polite; but had I spoken, I might have said: 
and what's the difference, be you Catholic, Protestant, Mormon, or anything else? Do you not all worship at that one, real, heart-felt, shrine? Are you not all smitten, 24/7, with one, immanent, all-embracing ideology, regardless of where I cast a stone in America?). Yes, Mammon is our national god; and Mammon-worship our national religion. All else is immaterial; all else is delusion. All else is fraud. Amen.

Money is only a symbol, though, for powerful, underlying social relations, drives and motivations; a simple commodity, but how complex its clammy reaches! What a certain solvent of all human relations! Only a medium of exchange, and an unreliable store of value - but how deeply it can penetrate the most guarded recesses of the social life! The most precious human artefacts, love, affection, regard, comfort, assurance, charity are all rendered saleable, when the domain of markets and money are allowed free, unrestricted, unhindered play; and the market, having taken over from all other means of social allocation, soon caters to all our needs, real, imaginary, frivolous, or sadistic.

Our dependence on markets becomes total, our 'needs' as dictated to in the marketplace become quite limitless, our ability to provision ourselves, emotionally and materially, outside of the cash nexus, shrinks radically, and gets reduced, astonishingly rapidly, to zero. We are abased to only the barest specialized functions necessary to command a measure of purchasing power, defined by our tasks, limited by our marketable skills, sold for our value, like so many degraded beasts of burden.

As a youth, in India, I witnessed the ineluctable processes of market expropriation at first hand. Our neighbor, in rural environs by the city of Chennai, was a petty farmer raising virtually all his family's needs on two acres of intelligently tilled land, combining a variety of horticultural crops well-adjusted to climate and terrain. He had two sons, whose ambitions, doused with the rampant fever of modernism, lay however elsewhere, outside of the family farm, in the meretricious Allure of the City. To put them through school, he was now obliged to raise funds. So he started to sell milk, as a side deal, to the local merchants who retailed it; soon, with advanced funds (provided by the retail merchants, quasi-masters already, subjecting him to standards, quotas, delivery times, etc.) he bought more cows, and the 'side-deal' burgeoned into a business, now his sole business, the more diversified farming activities being completely neglected (the sons were too busy with school to help).

Then one day, of a sudden, the milk market collapsed with the entry of State Dairies; and, in settlement of his debts, his little farm was taken away, and I last saw him out on the street, sitting by the kerb atop a small trunk carrying all his possessions, almost insane with grief, as his neighbors watched in horror from behind the slits of closed windows, sans home, sans cows, sans everything. The sons, with but a modicum of school skills, were now driven to the city in search of odd jobs; the old man, I am told, his wife having died of sheer heartbreak, after years of severe privation, lived on to secure an itinerant, part time, dairy-hand job with a State Dairy facility. The small, cheerful, family I knew had been gutted without remorse; from peasant to proletarian, one might say, in less than ten years, all courtesy of the vaunted 'magic' 
of the market. I suppose my economist colleagues, both U.S. and Indian, will pronounce it progress - and have their travesties believed by the gullible.

We in the west, not to mention the US, tend to think of ourselves as the Masters of the Universe, the chosen, the elect, the elite corps of thinkers, doers, and shakers of the world (you only have to see how Rambo bare-handedly cuts through hundreds of Asian savages, with that winning combination of brain and brawn, to be sold on that; quite apart from the real Vietnam War where these little 'Asian savages' routed, without ceremony, the mightiest men and military equipment on earth). This illusion is confirmed when we pay ourselves thirty to fifty times more, by way of income, than the average inhabitant of this planet (most likely living in Asia or Africa) for performing similar, sometimes identical tasks (we also award ourselves, as a side-note at the drop of a hat, spectacular medals, for the very slightest of misdeeds; there were more decorations awarded - some six thousand, or so - than actual soldiers sent in to stamp out tiny Grenada; the American crew that shot down an Iranian civilian jet, killing all on board, while based in Iranian territorial waters, in defiance of international law not to speak of the elementary norms of human decency - all took home medals in confirmation of their craven heroism).

But, are we really fifty times brighter, more savvy, more knowledgeable, than the poor sod who ekes out a humble, if non-American, existence in some heathen, pagan, underworld 'out there'? Frankly, having spent three decades in close contact with a fair cross-section of American society, I can safely say, with the most complete assurance, that I know of illiterate nomads who have a sounder conception of what makes the world go around, and their own place in it, than the self-centered, over-fed, arrogant, ignorant, deluded, media-blitzed, formula-quoting, chapter-and-verse toting, machine-brained, 'average' American.

Of course, it is trivially true that the best brains here match the best in the world, and it couldn't be otherwise; but there are few peoples in the world, to my knowledge, vested with less common sense, with less ordinary judgment, and with a lesser capacity to think for themselves: without summary, artificial, and mechanical aids. This supernal ignorance is not, as is sometimes implied, the simple result of a continent unfairly isolated from the world by two rather uncharitable oceans; it stems partly from the soaring arrogance of the larger 'system' that holds that the 'rest of the world' is just that - unfit and undeserving of attention (so that the average American college graduate can get by without being able to name, or identify on a map, even a mere five African countries, in his/her lifetime, as opposed to any college graduate in Africa, peasant though he may be, who can probably name most American states - and several American presidents as well), but also from a patented system of indoctrination that all but kills both negative capability and a critical imagination. The system has a real, vested interest in 'dumbing down' the populace.

In corporatism, one thinks, if at all, functionally, and no more; knowledge needs be 'useful', (supposedly) practical, and applied. Nonetheless, in terms of our skills 
and abilities to survive and deal with our habitat, both social and natural, in terms of effective control over the immediate means to life, we have registered regress and not progress; in this respect, the 'average American' was incomparably better off (so long as he/she was white), more skilled, and less ignorant, less dependent, in the eighteenth century than now. And this is a far greater tragedy than the fact that Japanese school children routinely outdo us in mathematics and the sciences, and that we rank, world's foremost - and now perhaps the only - superpower and all notwithstanding, forty-ninth in world literacy (a third of our adults cannot read above ninth-grade levels, not to mention the fact that aliteracy, i.e., people who can read, but won't, stands at a whopping 40 per cent).

I don't need to think, because, for a small fee, someone will do that for me. I don't need to create, because the Museum and the Art-Gallery can afford me creations, I don't need to govern, because the professional politician will function for me, I don't need to be entertaining because the record, the video, and the tape will pipe in the vital, if precooked, food for my starved senses. Most of us live thus, reduced, atomized, fragmented, idolized, robotized, paralyzed of human attributes, turning into uncritical, unfeeling, nuclei of controlled passivity.

The Uncertain Economy forces me to be saleable, at any place, at any time, without notice; so, it's goodbye to steady family on a regular basis, but we shall try and meet at Xmas, ma. Shall I marry, or move in with someone?; think economics, think cost-benefit think dollars and cents, before feelings, relations and affections. And if I do take the plunge unreflectively, there will, predictably, be alimony, and palimony, to worry about, sooner or later (a Canadian friend of mine just barely got married; he tells me, confidingly, that he has prudently started to save up an 'alimony fund', already). Beware - why take such risks?; cheaper to live alone and, ever so cautiously, try out casual relations (to the extent sustainable within my budget).

I have yuppie neighbors - 'dinks' actually, to be technical about it - who tell me, only semi-jocularly, that they cannot 'afford' children. They may be joking, but the economist who parodies this wit into science is not. He tells us children are a consumption good' whose costs (nuisance and other costs) need to be weighed against the stream of positive psychic income to be expected over a lifetime. Can we, at all, 'afford' to live?; in this, the richest nation in the world, many cannot (so life is not, always, 'cost-effective'; there's a 'rational' basis, after all, then, for suicide) - the poor, the unlucky, the elderly, and so on.

I know a man, a professional man, an educated, indeed a highly civilized man, who went through a terrible divorce, in the process being stripped of all his funds, property, and even his pension, by a wife who, secretly, had a lover and planned to remarry immediately after. He was in his forties when this tragedy occurred; he is in his sixties now, having lived alone for twenty years, his life wrecked, his career in shambles, his health ruinously impaired, and yet in all those years he dared not to meet another woman, or look for another companion in this, the loneliest of all human societies. He was afraid; 'My first wife took ninety per cent of all I had', he 
says, 'the next might take the remainder, and then where'll I be?'. He had decided he could not 'afford' another relationship; loneliness is cheaper, less risky, more bearable. So he lives on in dire misanthropy, misogyny, and desperation, substituting dogs (several of them) for human companionship.

The biggest GDP in the world, and growing bigger: and still, god help us, what utter, confounding, relentless, poverty! We are, most of us, too poor to survive marriage, to afford relations, to live with family, to cultivate friends, to find requisite time to raise children, to have independent views, opinions, principles; to care, to give, to sustain! Where has all the GDP gone? We are poor in our faculties, our senses, our measures of life, our standards, our norms, our sense of fellowship; in our appreciation of nature, in our regard for others, in our capacity to be human, in all our wretched, misshapen, twisted, bankrupt lives. And yet 99 per cent of our society believes this to be Progress, that we are number one, the one to watch, the life-style to emulate, the society to envy; few here have the memory, fewer still the imagination, to conceive of another world, another way of life, another form of society, less 'progressive', more benign, more convivial, where self-determination, and self-provisioning, catering to human and social needs might prevail, unmediated, in the main, by money, markets, and Moloch.

The largest, most productive, economy on earth, proclaim the smug, sponsored seers and the savants; and we all go about giddy with an imagined success, feeling superior to the silly riff-raff that inhabit the other parts of this planet. And in what does our vaunted productivity lie? In a rapacious, predatory, non-renewable, irrational consumption of the world's resources (almost a good 26\% per cent of which come our way, one way or other): our resources, their resources, everyone's resources. Who will take the measure of the damnable destruction, the almost unscalable Costs human, material, natural - underlying our giant turnover of output? Savage rapacity towards nature matched only by the self-same savagery in relation to anyone, and anything, who has stood between us and our boundless greed: workers, peoples, women, rivers, forests, cultures, nations - even the very air we breathe.

And are we richer, happier as a result? The true measure of 'affluence' for any society, is the balance struck between Needs and Resources; we are affluent, if our resources more than meet our needs, poor if it's the other way around. Let's compare ourselves to the Bushmen of Africa in this regard, or aboriginal peoples anywhere, and we get the real answer as to the scale of our riches. We, not they, are the desperately impoverished, the chronically poor, the inveterately discontented; never having enough, always short, always wanting more. And, no, we are not the most productive economy on earth, in terms of social/ecological efficiency, but the most ruinous, the most destructive, the most predacious, the most wasteful, of all human societies, past or present.

I still, fortunately, remember some happy faces in my lifetime; few (except for children not yet socialized into our particular, inimitable, brand of wretchedness although, the threshold for the Age of Induction is being reduced at an alarming rate, 
year by year) in that ilk, are American, or even European, for that matter - most were in Africa and Asia, supposedly amongst the most sub-humanly poor, the most abysmally miserable, parts of the world. We should all be so poor!

We are paraded, like dumb animals, besides the ever bountiful feast of technology, not designed to cut human drudgery and elevate human labor, which is the belief of the naïve, but only to replace it, of a sudden, and without notice, at lower cost, and higher profit; the endless gadgetry, gimmickry, and inventiveness, makes us, we are sure, the envy of a cheap, pharisaic, hollow world, that we have done our best, but at their peril, to craft in our own image. We know not what we have lost, or of what we are being stripped, denuded, of daily, in this civilization of concrete, granitic, grasping, materiality.

The market provides, we are taught by those who own it, control it, and leech off its spoils; and we fail to see that the market also deprives, takes away, reduces, and ravages. The market has given us the teeming ghetto, the abandoned housing project, the downtown no-man's land, the far boondocks, where you intrude only at peril; the Streets where none may walk, the parks that none may use, the Commons that none may share; the market has razed our landscape, poisoned our waters, polluted the air, and ravished the good earth; the market has come between us and those we love, be they people, principles, ideas, dreams, or aesthetics.

Markets expand, and our lives shrink: our means of sustenance despoil, and we are brought to the brink of chronic destitution and dependency (80 per cent of the population of Bangladesh, eating fewer calories than what we might assign to paupers in our imagination, has less access to food today, some two centuries or so of both English colonialism and domestic capitalism notwithstanding, than they had in the time of the rule of the Mogul Emperor Akbar, aeons ago; similarly, nature's vagaries apart, it was the hot-house commercialization of agriculture, and the consequent ruin of the top-soils, that crafted the purely socially contrived disaster of the Ethiopian famine).

Markets produce the continuously recycled illusion that are our needs are limitless, our cravings infinite; that we are pathologically obsessive Consumers before we are anything else, friends, relatives, citizens, social beings, producers, creators, and artists - and that the market will satisfy these urgings, if only of the provident, from here to eternity. But living is not consuming alone, and life is not a craven tale of a boundless lust for privatized, personal, self-indulgent, material satiation, like a pig in a big trough wallowing all by itself; we are, incurably social beings that must not be trapped in the web of our own artefacts, ensnared in the designs of Capital, enmeshed in the schemes of profiteers, or caught in the plans of those who seek to amass profits, expand commodities, and reduce our lives, destroying the very founts of our wellbeing, proportionately.

Perhaps I paint with too large a brush; am I not lumping together fish and fowl in this grim Litany of Greed? The rich may be driven by crass materiality; but what of the poor, working class, blue collar America that is driven only by scarcity, want, 
need, hunger, poverty, insecurity and stark dispossession? They, who rise early, and return late, day after day, without rest or respite, at barely a minimum wage, without insurance, social or private, without benefits, without contracts, for lifetime upon lifetime, on the margins of social existence, with a life principally consisting of toil to earn their bread, alcohol to douse their pains, and violence to vent their frustration?

Is 'materiality' not thrust upon them by their wretchedness, their squalor - moral and material - and their dire straits? Do they not greed only for sustenance, crave only for survival, and desire only for alms? To a great extent this must be admitted as true; but America is a one-dimensional society where mores differ little from age to age, class to class, gender to gender, race to race. All are prey, all are victims, to the dominant ethic of 'Me first, and the devil take the hindmost'. But the petty greed of the toilers is cut of a different clay, to an extent the dictate of necessity, the wages of deprivation. Their lives of brutish, unfulfilled, unrequited, labors are born of want, bred of desperation, and fueled by fear. Sociologists write glibly of the 'hidden' injuries of class; had they eyes, instead of analyses, they could see the entirely visible scars, read the vicissitude thereof, comprehend the stark deprivation therein.

But, such qualifications aside, one must not make too much of 'material necessities' obstructing the development of a personal or a social ethic. Part of the great drama of human history is people refusing to be bound by circumstances, indeed rising beyond them. Poverty and deprivation do not automatically, ipso facto, justify, as our miserable liberal ideology of materialism seems to imply, let alone license, unbounded opportunism. Just one example; India's struggle for independence from Imperial Britain was assisted, in part and for a time, by English textile-workers going on strike - at immediate cost to themselves - explicitly in support of India's independence movement. Obviously, such acts of altruistic heroism are rare (although not quite as rare as modern ideology tends to portray it); but they do show that it is not at all impossible, given decent values, social consciousness, and political understanding (all of which were in display in the British working-class movement of the inter-War period).

Another example: many of India's teeming millions live in dire, abject, poverty, victims of the savage ruthlessness of their ruling classes, and yet it occurs to but a few to go on a rampage, burning, killing and pillaging among their betters, either in anger, frustration, or sheer desperation; their heroic fortitude, their supernal calm, their stoic pacifism, is as much a tribute to their ineffable civilizational genius as it is a thunderous indictment of the wretched political economy that has uprooted their lives, destroyed their vocations, and stripped them of their means of subsistence.

The truth is quite compelling: we are, each one of us, 'free to choose' the terms of our personal sell-out to the powers that be, to define the balance between our assessment of survival requirements and the plea for right actions demanded by our values; we are free, in the ultimate analysis, either to cut a Faustian deal, with that which oppresses us, or not. 
Materiality rents a hard-nosed philosophy - pragmatism (small wonder that America, and not Nepal, produced a William James - the most representative of all American philosophers); not because it is philosophically inclined, but because it finds in it an eminently serviceable ideology. Let me simplify: I will rather starve than slaughter a cow, says the Hindu, adamantly; I would rather starve, than eat a pig, says the Moslem, equally obstreperous; I would rather not starve, says the American, period. That is pragmatism; where anything goes, so long as you get your way, achieve your ends; principles are only handicaps, and get in the way. It is the hard-headed ideology of a business civilization, of course, and shared by commerce quite generally; but America does it better than anyone else.

Civilizational norms are necessarily transcendent, all embracing, values - cutting across all divisions of caste, class and creed; in a fit of passion, Karl Marx once complained bitterly that (nineteenth) century England had a 'bourgeois' (i.e., commercially corrupt) aristocracy, a corrupt capitalist class and a corrupt working-class, that is to say, he deemed all of England corrupt and beyond redemption, succumbed to crass materiality, and relentless venality. And that was still nineteenth century England, and not fully broken yet with its own tradition, history, and memory: but could hoary old England ever hope to compete, in this regard, with her late blooming, errant, matricidal, gargantuan foster child, across the ocean?

As Russel Means, Native American prophet, philosopher, and activist put it, in an address, the European Persuasion, despite the tragic revealments all around us, is still impervious to any abiding sense of loss as it goes about its daily depredations. In his words:

'After all, their philosophers have despiritualized reality so there is no satisfaction (for them) to be gained in simply observing the wonder of a mountain or a lake or a people in being. Satisfaction is measured in terms of gaining material - so the mountain becomes gravel and the lake becomes coolant for a factory...'

There are Two different paths to riches, wrote Gandhi; One is the way of multiplying material wealth beyond bounds, with all its depredations, parasitisms, conflicts, and vicissitudes - the Other Way is to simply reduce our all too human 'needs' to the domain of plausibility, civility, and grace. This latter is the 'other way' that all of us need to learn some day; it's perhaps yet an option now, although I doubt that, but it may well be dire necessity in the years to come when the world, hard pressed even now to supply merely America with the ingredients of the American Way of Life, is compelled to yield the same to an entire world gone over, sold out completely, to this frenzied, crapulent Way (capitalist gluttony has already given us two World Wars to remember; how many more will the New World Order engender?). When Indian policy makers, after independence, sought eagerly to replicate England, in adopting a capitalist path of development, Gandhi observed that it took a good two-thirds of the resources of the existing globe to fund and fuel the English miracle: how many globes, he asked, would India need to match the English achievement? 
We are now busy inventing and reinventing the world after our own grandiloquent materiality; even the mighty Soviets, with seventy years of defiant Bolshevik theory and practice behind them, were finally humbled by the sweep of our ideology, the power of our war machines, the abundance of our teflon. Country after country, like modern China today, and most of India tomorrow, is now ready to sink right into our mire, to wallow in our very own wastelands, to dance our own patented, unwholesome, jigs. Perhaps it is time for us to take stock and think: do we really want the rest of the world to think, act, look, and be, like New York (the only prison, it has been said, that was built lovingly by its own inmates)? 